\title{
The Application of Financial Analysis System of Enterprise Core Competitiveness
}

\author{
-A Case Study of the Listed Company in Shanxi Province
}

\author{
Xiaojun Deng \\ School of Economics and Management \\ Xi'an Shiyou University \\ Xi'an, Shanxi, 710065, China
}

\author{
Qing $\mathrm{Yu}$ \\ School of Economics and Management \\ Xi'an Shiyou University \\ Xi’an, Shanxi, 710065, China
}

\begin{abstract}
According to the core, leading, coordinative and dynamic nature of the enterprise core competitiveness, a system that consists of four enterprise financial analysis indexes, namely, human capital return on investment, $R \& D$ and innovation capability, cash balance capacity and return rate on capital investment is set up. This paper attempted to test the reasonability and feasibility of the practical application of this system. Therefore, it made the empirical test on the five years' financial data of 35 listed companies in Shaanxi province, and found that the fitting effect of the four financial analysis indexes was good, and the explanatory degree of each indicator and the enterprise core competitiveness is $72.26 \%$. As a consequence, it is viable to adopt the four indicators to reflect and explain enterprise core competitiveness.
\end{abstract}

Keywords-core competitiveness; financial analysis system; application

\section{RESEARCH DESIGN OF FINANCIAL ANALYSIS INDEXES}

\section{A. Sample selection and data sources}

There are 46 listed companies, most of which are engaged in manufacturing industry in Shanghai and Shenzhen stock exchanges. Among them, 35 companies are selected as the samples in this paper based on the construction and the application of financial analysis system of enterprise core competitiveness. Excluded are the ST Xinghua and ST Hongsheng which have been under the special treatment, 7 companies that have been listed for shorter than five years such as Chenxi Aviation, companies whose data are out of the standard such as Shanguotou A and Western Securities. The data of the 35 selected companies are mainly from the 2012 to 2016 annual reports which are extracted from the yearly disclosures of Shanghai Stock Exchange, Shenzhen Stock Exchange and eastmoney.com. All indexes were sorted out through the formula obtained from normative research. EViews8.0 was used for data statistics and analysis in the empirical test.

\section{B. Research hypotheses}

The four financial analysis indicators constructed before correspond respectively to the characteristics of the core competitiveness of enterprises. Before verifying the correlation, the following hypotheses are made in this paper.

Fund Project: the research work of this dissertation is the periodic achievement of Xi'an Shiyou University High-Level Talent Support Program named on Invisible Financial Capital of Corporate Finance (No.0109-290088283)
Hypothesis 1: the core competitiveness of enterprises is positively correlated with the return on investment of human capital [1]. As the core resource of an enterprise, human capital is a kind of local competitive advantage. Although it only accounts for a small part in the development of an enterprise, it serves as a powerful backup and can make the company invincible in fierce competition.

Hypothesis 2: there is a positive correlation between core competitiveness and $\mathrm{R} \& \mathrm{D}$ and innovation capability [2]. The R\&D and innovation capability represents the independence ability of enterprises, which, to some extent, determines the degree of core competitiveness of enterprises. The greater the $\mathrm{R} \& \mathrm{D}$ and innovation capability, the harder it will be for the counterparts to imitate, and the enterprise will obtain a longer-lasting leadership.

Hypothesis 3: there is a positive correlation between core competitiveness and cash balance capability ${ }^{[3]}$. Cash balance refers to the coordination of internal superior resources of an enterprise. Good cash balance ability is manifested in the reasonable collocation of working capital and the sound resource integration, which provides capital guarantee for the smooth operation of the enterprise and thus laying the foundation for the core competitiveness of the enterprise.

Hypothesis 4: the core competitiveness of enterprises is positively correlated with the profit of capital investment ${ }^{[4]}$. To obtain profit is one of the important goals of enterprise operation and development. Therefore, the enterprise has invested a large amount of capital to ensure its efficient operation. In the dynamic change and development, enterprises reap income and consolidate their ability of sustainable development through the cycle of investment and profit. The more dynamic the enterprise is, the more sustainable the income from capital investment will be, and the higher its core competitiveness will be.

\section{Variable description and model establishment}

1) Definition of independent variable

Human capital investment rate of return $\left(\mathrm{X}_{1}\right)$ : human capital investment rate of return $=$ net income of human capital investment/cost of human capital $=$ net profit/payment to employee 
$R \& D$ and innovation ability $\left(\mathrm{X}_{2}\right)$ : $R \& D$ and innovation ability=(development expenditure+intangible assets)/operating income

Cash balance capacity $\left(\mathrm{X}_{3}\right)$ : cash balance capacity = working capital-working capital requirement (take the logarithm of the absolute value of the result)

Return rate on capital investment $\left(\mathrm{X}_{4}\right)$ : return rate on capital investment $=$ core profit $/$ total invested capital $=$ (operating income - operating cost - operating taxes and surcharges administrative expenses - sales expenses - financial expenses)/ (average balance of equity or paid-in capital + average balance of capital accumulation fund)

\section{2) Definition of dependent variable}

In the standard, stable and mature market economy trading environment, the market value of assets quantifies the investment value of enterprises. Similarly, the core competitiveness of enterprises changes dynamically with the fluctuation of the market value of enterprise assets. Using the asset to market capitalization ratio, it can reasonably reflect the core competitiveness of the enterprise without being influenced by the size of the company.

Asset to market capitalization ratio $(\mathrm{Y})$ : asset to market capitalization ratio $=$ annual total market value of assets/total assets. The larger the index value is, the stronger the core competitiveness of the enterprise is. The market value of assets is the total value of stocks calculated by multiplying the market price of listed companies in the securities market by the total number of shares issued.

TABLE I. VARIABLE DESCRIPTION

\begin{tabular}{|l|l|l|}
\hline Types & Variables & Calculation formula \\
\hline $\begin{array}{l}\text { Dependent } \\
\text { variable }\end{array}$ & $\begin{array}{l}\text { Asset to market } \\
\text { capitalization ratio(Y) }\end{array}$ & $\begin{array}{l}\text { annual total market value of } \\
\text { assets/total assets }\end{array}$ \\
\hline \multirow{5}{*}{$\begin{array}{l}\text { Independent } \\
\text { variables }\end{array}$} & $\begin{array}{l}\text { Human capital } \\
\text { investment rate of } \\
\text { return }\left(\mathrm{X}_{1}\right)\end{array}$ & $\begin{array}{l}\text { net profit/payment to employee } \\
\text { ability }\left(\mathrm{X}_{2}\right)\end{array}$ \\
\cline { 2 - 3 } & $\begin{array}{l}\text { Cash balance } \\
\text { capacity }\left(\mathrm{X}_{3}\right)\end{array}$ & $\begin{array}{l}\text { (development expenditure+ } \\
\text { intangible assets)/operating } \\
\text { income }\end{array}$ \\
\cline { 2 - 3 } & $\begin{array}{l}\text { Return rate on capital } \\
\text { investment }\left(\mathrm{X}_{4}\right)\end{array}$ & $\begin{array}{l}\text { working capital - working capital } \\
\text { requirement }\end{array}$ \\
\hline
\end{tabular}

\section{3) Model establishmen}

According to the above definition and the research purpose of this paper, combined with the requirements of regression model analysis, the model is established as follows:

$$
Y_{i t}=\alpha_{i}+b_{1} X_{1_{t}}+b_{2} X_{2 i}+b_{3} X_{3 i}+b_{4} X_{4 i}+\mu_{u t}
$$

$\mathrm{Y}$ represents the asset to market capitalization ratio; $\mathrm{X}_{1}, \mathrm{X}_{2}$, $\mathrm{X}_{3}$ and $\mathrm{X}_{4}$ respectively stand for the human capital investment rate of return, $\mathrm{R} \& \mathrm{D}$ and innovation ability, cash balance capacity and return rate on capital investment. $b_{1}, b_{2}, b_{3}$ and $b_{4}$ refer to the model parameters of four independent variables respectively. $\alpha$ is the constant term; $\mu$ is the stochastic disturbance. The subscript $\mathrm{i}$ is the cross-section number, representing different enterprises; the subscript $t$ is the length of time, representing the five-year-period from 2012 to 2016.

\section{THE EMPIRICAL TEST OF THE ANALYSIS INDEXES}

\section{A. Correlation analysis}

The purpose of this research is to construct financial analysis indexes that can well reflect the core competitiveness of enterprises from the perspective of financial accounting, so as to show the status of the core competitiveness of enterprises. To a certain extent, the four main characteristics of core competitiveness are correlated, so the correlation between various variables can be accepted.

TABLE II. VARIABLES CORRELATED COEFFICIENTS (PEARSON CORRELATED)

\begin{tabular}{|c|c|c|c|c|}
\hline & $\mathrm{X}_{1}$ & $\mathrm{X}_{2}$ & $\mathrm{X}_{3}$ & $\mathrm{X}_{4}$ \\
\hline $\mathrm{X}_{1}$ & 1 & & & \\
\hline $\mathrm{X}_{2}$ & -0.217 & 1 & & \\
\hline $\mathrm{X}_{3}$ & 0.136 & 0.006 & 1 & \\
\hline $\mathrm{X}_{4}$ & 0.315 & -0.143 & 0.099 & 1 \\
\hline
\end{tabular}

“**” represents those that are significantly correlated at the level of 0.01 . “*” denotes those that are that are significantly correlated at the level of 0.05 .

\section{B. Multiple regression analysis}

The empirical analysis of this paper involves the data of 35 listed companies in Shaanxi province from 2012 to 2016. When making empirical analysis, we need to choose the right models at the beginning. First, the $\mathrm{F}$ test is used to determine to choose the mixed effects model or entity fixed effects model. Second, Hausman test determines whether to adopt the entity fixed effects model or the entity random effects model. In the empirical test, the maximum likelihood ratio test of $\mathrm{F}$ statistics was carried out through Eviews8.0 software. Then mixed effect model and individual fixed effect model regression were conducted on the sample data. Finally, choose the mixed effects model or individual fixed effects model according to the $F$ value of the regression results.

\section{1) Mixed effects model}

TABLE III. THE GOODNESS OF FIT TEST OF MIXED REGRESSION MODEL

\begin{tabular}{|l|r|l|r|}
\hline R-squared & 0.146830 & Mean dependent var & 1.805755 \\
\hline Adjusted R-squared & 0.131862 & S.D. dependent var & 1.628462 \\
\hline S.E. of regression & 1.517302 & Akaike info criterion & 3.694336 \\
\hline Sum squared resid & 393.6771 & Schwarz criterion & 3.766674 \\
\hline Log likelihood & -319.2544 & Hannan-Quinn criter. & 3.723679 \\
\hline Durbin-Watson stat & 0.762343 & \multicolumn{2}{|c|}{} \\
\hline
\end{tabular}

According to the regression results, $\mathrm{R}^{2}$ equals 0.146830 and the adjusted $\mathrm{R}^{2}$ equals 0.131862 .

\section{2) Entity fixed effects model}

TABLE IV. THE GOODNESS OF FIT TEST OF ENTITY FIXED EFFECT MODEL

\begin{tabular}{|l|r|l|l|}
\hline R-squared & 0.722644 & Mean dependent var & 2.566050 \\
\hline Adjusted R-squared & 0.645147 & S.D. dependent var & 1.412220 \\
\hline S.E. of regression & 0.957838 & Sum squared resid & 124.7737 \\
\hline F-statistic & 9.324855 & Durbin-Watson stat & 1.685437 \\
\hline Prob(F-statistic) & 0.000000 & & \\
\hline
\end{tabular}

According to the regression results, $\mathrm{R}^{2}$ equals 0.722644 and the adjusted $\mathrm{R}^{2}$ equals 0.645147 . 
3) F-test

TABLE V. F TEST RESULT

\begin{tabular}{|l|c|l|c|}
\hline Effects Test & Statistic & d.f. & Prob. \\
\hline Cross-section F & 8.718611 & $(34,136)$ & 0.0000 \\
\hline
\end{tabular}

It can be seen from the comparison between table 4 and table 5 that the goodness of fit of entity fixed effects model is higher than that of mixed effects model. As can be seen from table 6 , the value of $\mathrm{F}$ is 8.718611 , and $\mathrm{P}=0.0000<0.05$, so we need to establish entity fixed effects model rather than the mixed effect model. Next, Hausman test is needed to further select the model and determine which is the most appropriate model.

\section{4) Hausman test}

TABLE VI. HAUSMAN TEST RESULTS

\begin{tabular}{|c|c|c|c|}
\hline Test Summary & Chi-Sq.Statistic & Chi-Sq. d.f. & Prob. \\
\hline $\begin{array}{c}\text { Cross-section } \\
\text { random }\end{array}$ & 48.229803 & 4 & 0.0000 \\
\hline
\end{tabular}

According to the above value of the chi-sq statistic, the value of $P$ is 0.0000 which is smaller than 0.05 . Therefore, we should establish the entity fixed effect regression model, so the regression model established above is applicable.

5) Regression analysis results

This part is analyzed by EViews8.0, and the regression analysis results are as follows:

TABLE VII. REGRESSION RESULTS

\begin{tabular}{|c|c|c|c|c|}
\hline Variable & Coefficient & Std. Error & t-Statistic & Prob. \\
\hline C & -0.579830 & 0.911783 & -0.635929 & 0.5259 \\
\hline$?$ & 0.000733 & 0.032357 & 0.022649 & 0.9820 \\
\hline$?$ & 0.346725 & 0.380624 & 0.910939 & 0.3639 \\
\hline$?$ & 0.117626 & 0.046211 & 2.545414 & 0.0120 \\
\hline$?$ & 0.192357 & 0.316909 & 0.606978 & 0.5449 \\
\hline \multicolumn{5}{|c|}{\begin{tabular}{|l|l|} 
Fixed Effects (Cross) & \\
\end{tabular}} \\
\hline $1--\mathrm{C}$ & 3.239835 & & & \\
\hline $2--\mathrm{C}$ & -0.749715 & & & \\
\hline $3--\mathrm{C}$ & 0.966328 & & & \\
\hline 4--C & 0.368235 & & & \\
\hline 5--C & -1.293685 & & & \\
\hline 6--C & -0.443434 & & & \\
\hline 7--C & -1.223066 & & & \\
\hline 8--C & -1.172702 & & & \\
\hline 9--C & -1.366873 & & & \\
\hline 10--C & -0.660003 & & & \\
\hline $11--\mathrm{C}$ & -0.954415 & & & \\
\hline 12--C & -0.233830 & & & \\
\hline 13--C & 1.004521 & & & \\
\hline 14--C & -1.033540 & & & \\
\hline 15--C & 0.737578 & & & \\
\hline 16--C & -1.465450 & & & \\
\hline 17--C & -0.574065 & & & \\
\hline 18--C & -0.670329 & & & \\
\hline 19--C & -1.072481 & & & \\
\hline 20--C & -0.084442 & & & \\
\hline 21--C & 0.804536 & & & \\
\hline 22--C & -0.267698 & & & \\
\hline
\end{tabular}

\begin{tabular}{|c|c|c|c|}
\hline $23--\mathrm{C}$ & 0.572995 & & \\
\hline $24--\mathrm{C}$ & 5.869438 & & \\
\hline $25--\mathrm{C}$ & -0.879543 & & \\
\hline $26--\mathrm{C}$ & -0.702697 & & \\
\hline 27--C & 0.052094 & & \\
\hline $28--\mathrm{C}$ & 0.274080 & & \\
\hline $29--\mathrm{C}$ & -0.159161 & & \\
\hline $30--\mathrm{C}$ & 1.007813 & & \\
\hline 31--C & 0.951726 & & \\
\hline 32--C & -0.107839 & & \\
\hline 33--C & -0.625818 & & \\
\hline 34--C & -0.325652 & & \\
\hline 35--C & 0.217260 & & \\
\hline \multicolumn{4}{|c|}{ Effects Specification } \\
\hline \multirow{2}{*}{\multicolumn{4}{|c|}{$\begin{array}{c}\text { Cross-section fixed (dummy variables) } \\
\text { Weighted Statistics }\end{array}$}} \\
\hline & & & \\
\hline R-squared & 0.722644 & Mean dependent var & 2.566050 \\
\hline Adjusted R-squared & 0.645147 & S.D. dependent var & 1.412220 \\
\hline S.E. of regression & 0.957838 & Sum squared resid & 124.7737 \\
\hline F-statistic & 9.324855 & Durbin-Watson stat & 1.685437 \\
\hline Prob(F-statistic) & 0.000000 & & \\
\hline \multicolumn{4}{|c|}{ Unweighted Statistics } \\
\hline R-squared & 0.708634 & Mean dependent var & 1.805755 \\
\hline Sum squared resid & 134.4446 & Durbin-Watson stat & 1.459592 \\
\hline
\end{tabular}

The data listed as coefficients are the regression coefficients of the model constructed in this paper. By substituting the regression coefficients and constant terms into the regression model, the following regression equation can be obtained:

$Y=-579830+0.0007333 X_{1}+0.346725 X_{2}+0.117626 X_{3}+0.192357 X_{4}$

\section{Core competitiveness ranking of the 35 companies}

This paper uses the human capital investment rate of return, R\&D and innovation ability, the cash balance ability and return rate on capital investment as independent variables to reflect four basic characteristics of enterprise core competitiveness, and leverage asset to market value ratio as the dependent variable to quantitative reflect enterprise's core competitiveness. In Table 8 according to the value of assets ratio, the 35 listed companies' core competitiveness is ranked by average index value of the five year from 2012 to 2016. The greater the value is, the enterprise core competitiveness level is higher. The average values of the four basic financial indicators are listed in turn. 
TABLE VIII. RANKING OF CORE COMPETITIVENESS (2012-2016)

\begin{tabular}{|c|c|c|c|c|c|c|}
\hline $\begin{array}{l}\text { Ran } \\
\text { king }\end{array}$ & Company & $\begin{array}{c}\text { Asset to market } \\
\text { capitalization } \\
\text { ratio (average) }\end{array}$ & $\begin{array}{l}\text { Human capital investment } \\
\text { rate of return (average) }\end{array}$ & $\begin{array}{c}\text { R\&D and } \\
\text { innovation } \\
\text { ability(average) }\end{array}$ & $\begin{array}{c}\text { Cash balance } \\
\text { capacity(average) }\end{array}$ & $\begin{array}{l}\text { Return rate on capital } \\
\text { investment(average) }\end{array}$ \\
\hline 1 & Ligeance Aerospace & 8.030104 & 4.102374 & 1.206419 & 19.538444 & 0.108971 \\
\hline 2 & Baoguang & 4.701544 & 0.185205 & 0.003522 & 17.166472 & 0.108938 \\
\hline 3 & Fenghuodianzi & 2.720865 & 0.217936 & 0.066484 & 19.455556 & 0.117865 \\
\hline 4 & Broadcom shares & 2.704329 & 0.111277 & 0.282307 & 18.495959 & 0.031523 \\
\hline 5 & Xi’an Tousiam & 2.671104 & 0.087953 & 0.086670 & 18.890012 & -0.046550 \\
\hline 6 & Xi’an Yinshi & 2.587755 & 0.022870 & 0.065353 & 18.668101 & -0.013910 \\
\hline 7 & Dagang & 2.567750 & 1.954385 & 0.048323 & 20.174587 & 0.097499 \\
\hline 8 & Jinhua & 2.463363 & 0.710171 & 0.087556 & 18.661888 & 0.065768 \\
\hline 9 & Caissa Tourism & 2.304849 & 0.336238 & 0.048850 & 19.234677 & 0.166345 \\
\hline 10 & Astropulsion & 2.194449 & 0.415344 & 0.088557 & 20.126176 & 0.039866 \\
\hline 11 & Zhongzaizihuan & 2.109642 & 0.020845 & 0.222402 & 19.696163 & 0.407055 \\
\hline 12 & Shaanxi Jinye & 2.028266 & 0.513519 & 0.228410 & 18.892028 & 0.167640 \\
\hline 13 & Jinmu & 1.810158 & 0.303708 & 0.159147 & 22.078861 & 0.027192 \\
\hline 14 & AVIC ZEMIC & 1.686177 & 0.423154 & 0.096646 & 19.671101 & 0.136149 \\
\hline 15 & $\begin{array}{l}\text { Qujiang Cutural } \\
\text { Tourism }\end{array}$ & 1.674383 & 0.259983 & 0.154125 & 18.080147 & 0.113285 \\
\hline 16 & Tong Petrotech Inc & 1.601552 & 0.378830 & 0.047142 & 19.729044 & 0.016990 \\
\hline 17 & Typical & 1.538627 & -0.027409 & 0.148767 & 19.663076 & -0.063254 \\
\hline 18 & Zhaonghuanzhuangbei & 1.457385 & 0.254570 & 0.188473 & 19.438421 & 0.056478 \\
\hline 19 & Shaanxigas & 1.364431 & 1.902264 & 0.050688 & 19.689430 & 0.274145 \\
\hline 20 & Jianshejixie & 1.298059 & -0.486002 & 0.052677 & 16.562404 & -0.019495 \\
\hline 21 & $\begin{array}{l}\text { AECCAERO } \\
\text { ENGINE }\end{array}$ & 1.295433 & 0.213691 & 0.080295 & 20.865716 & 0.097368 \\
\hline 22 & Zonghang Airplane & 1.251715 & 0.087446 & 0.026979 & 21.042418 & 0.036341 \\
\hline 23 & Guoji Yixue & 1.169015 & 0.721578 & 0.092537 & 19.909782 & 0.232116 \\
\hline 24 & Guangdian & 1.131510 & 0.237473 & 0.032600 & 19.121753 & 0.128455 \\
\hline 25 & Baoti & 1.076119 & -0.060201 & 0.054179 & 20.279950 & 0.007636 \\
\hline 26 & Longji & 1.026068 & 0.760483 & 0.042693 & 20.754480 & 0.149778 \\
\hline 27 & Caihong & 0.931718 & -5.050036 & 0.518550 & 20.257026 & -0.071543 \\
\hline 28 & Baode & 0.879863 & 0.831458 & 0.261954 & 19.667999 & 0.047830 \\
\hline 29 & Qinchuan & 0.841792 & -0.113104 & 0.091844 & 17.948867 & -0.097214 \\
\hline 30 & Shaangu & 0.823337 & 1.053449 & 0.042845 & 22.484726 & 0.189396 \\
\hline 31 & China Xidian & 0.798622 & 0.354634 & 0.134090 & 22.883695 & 0.035614 \\
\hline 32 & Jianruiwoneng & 0.693664 & 0.379770 & 0.225318 & 19.198651 & 0.048391 \\
\hline 33 & Yanchanghuajian & 0.680674 & 0.338282 & 0.014742 & 20.224774 & 0.254130 \\
\hline 34 & $\begin{array}{l}\text { Western metal } \\
\text { material }\end{array}$ & 0.599252 & 0.052896 & 0.177059 & 19.993492 & -0.057394 \\
\hline 35 & CCOOP Group & 0.487843 & 0.271371 & 0.069560 & 21.242345 & 0.052766 \\
\hline
\end{tabular}

\section{CONCLUSION}

1. Goodness-Of-Fit. That the determination coefficient in the regression results is 0.722644 indicates that the model fits well. In the goodness of fit test, the four independent variables set in the formula can explain $72.26 \%$ of the variation of dependent variables, indicating that the model has a good degree of fitting. Therefore, these four financial analysis indicators can be used to reflect and explain the core competitiveness of enterprises.

2. Regression coefficient. It can be seen from the Table 7 that the symbols of the regression coefficients of the four independent variables are consistent with the actual economic significance, which proves the four hypotheses above. Moreover, the regression results of human capital investment return rate, $R \& D$ and innovation ability and return rate on capital investment are not very significant, indicating that the impact of the three indicators on enterprises may need a long time to take effect, or there may be a certain lag, thus being unable to quickly reflect the core competitiveness of the enterprise. Indicators are also affected by many factors. Taking the human capital investment rate of return as an example, the return on human capital investment is also subject to factors such as the amount of enterprise investment, employees' skills and the value improvement.

\section{REFERENCES}

[1] Klein J, Gee D, Jones H. Analyzing Clusters of Skills in R\&D Core Competence[J]. R\&D Management,1998(1):37-42

[2] Gallon M., Klein D. Putting core competence into practiced[J]. Research Technology Management,1995(5):20-28

[3] Durand T. Strategizing for Innovation: Competence Analysis in Assessing Strategic Change[J]. Competence-based Strategic Management, 1995(3):127-150

[4] C.K.Prahalad, Gary Hamel. The Core Competence of the Corporation[J].Harvard Business Review,1990(5):79-91 